\title{
Usefulness of Fetopathological Examination in the Diagnosis of Skeletal Dysplasias
}

\author{
Sihem Darouich ${ }^{1 *}$, Nadia Boujelbene ${ }^{2}$, Soumeya Gaigi ${ }^{3}$ and Aida Masmoudi ${ }^{3}$ \\ ${ }^{1}$ Fetopathology Unit, University Hospital Habib Bougatfa, Bizerte, Tunisia \\ ${ }^{2}$ Department of Pathology, Salah Azaiez Institute, Tunis, Tunisia \\ ${ }^{3}$ Department of Embryo-Fetopathology, Maternity and Neonatology Center, Tunis, Tunisia
}

The skeletal dysplasias (SD) are the most common of the fetal genetic skeletal disorders. Classification of these conditions is based on clinical, radiological and pathological criteria [1]. The identification of an increasing number of genes involved in these disorders led to consider a molecular classification that groups phenotypically different conditions caused by mutations in the same gene [2]. Thus, the SD are composed of distinct groups of squeletal disorders covering a wide spectrum of gravity. However, this classification is still hybrid because the molecular defects have not yet been identified in all cases of SD [2]. Prenatal imaging can detect early fetal skeletal anomalies of varied severity and prognosis. It can accurately predicts lethality, based on the identification of pulmonary hypoplasia and severe limb shortening, but often raises a

\begin{tabular}{|c|c|c|}
\hline $\begin{array}{l}\text { Group/Name of } \\
\text { Disorder }\end{array}$ & Skeletal dysplasia & $\begin{array}{l}\text { Number of } \\
\text { cases }(\%)\end{array}$ \\
\hline $\begin{array}{l}\text { Osteogenesis } \\
\text { imperfecta and } \\
\text { decreased bone } \\
\text { density group (group } \\
\text { 25) }\end{array}$ & $\begin{array}{l}\text { Osteogenesis imperfecta, perinatal lethal, } \\
\text { severe and moderate forms }\end{array}$ & $21(29)$ \\
\hline $\begin{array}{l}\text { FGFR3 } \\
\text { chondrodysplasia } \\
\text { group (group 1) }\end{array}$ & $\begin{array}{l}\text { Thanatophoric dysplasia type } 1 \text { (TD1) and type } \\
2 \text { (TD2) }\end{array}$ & $18(25)$ \\
\hline $\begin{array}{l}\text { Ciliopathies with major } \\
\text { skeletal involvement } \\
\text { group } 9\end{array}$ & $\begin{array}{l}\text { Chondroectodermal dysplasia (Ellis-van } \\
\text { Creveld) } \\
\text { Short rib-polydactyly syndrome (SRPS) type } 3 \\
\text { (Verma-Naumoff) } \\
\text { Asphyxiating thoracic dysplasia (ATD; Jeune) } \\
\text { Short rib-polydactyly syndrome (SRPS) type } 2 \\
\text { (Majewski) }\end{array}$ & $9(12)$ \\
\hline $\begin{array}{l}\text { Sulphation disorders } \\
\text { group (group 4) }\end{array}$ & $\begin{array}{l}\text { Achondrogenesis type 1B (ACG1B) } \\
\text { Diastrophic dysplasia (DTD) }\end{array}$ & $7(10)$ \\
\hline $\begin{array}{l}\text { Abnormal } \\
\text { mineralization group } \\
\text { (group 26) }\end{array}$ & Hypophosphatasia, perinatal lethal form & $3(4)$ \\
\hline $\begin{array}{l}\text { Type } 2 \text { collagen group } \\
\text { (group 2) }\end{array}$ & $\begin{array}{l}\text { Hypochondrogenesis } \\
\text { Kniest dysplasia }\end{array}$ & $2(3)$ \\
\hline $\begin{array}{l}\text { Perlecan group (group } \\
5 \text { ) }\end{array}$ & $\begin{array}{c}\text { Dyssegmental dysplasia, Silverman-Handmaker } \\
\text { type }\end{array}$ & $2(3)$ \\
\hline $\begin{array}{l}\text { Filamin group and } \\
\text { related disorders } \\
\text { (group 7) }\end{array}$ & $\begin{array}{l}\text { Osteodysplasty Melnick-Needles } \\
\text { Otopalatodigital syndrome type } 2\end{array}$ & $2(3)$ \\
\hline $\begin{array}{l}\text { Severe } \\
\text { spondylodysplastic } \\
\text { dysplasias (group 14) }\end{array}$ & Achondrogenesis type 1A (ACG1A) & $2(3)$ \\
\hline $\begin{array}{l}\text { Campomelic dysplasia } \\
\text { and related disorders } \\
\text { (group 18) }\end{array}$ & $\begin{array}{l}\text { Campomelic dysplasia (CD) } \\
\text { Stûve-Wiedemann dysplasia }\end{array}$ & $2(3)$ \\
\hline $\begin{array}{l}\text { Chondrodysplasia } \\
\text { punctata (CDP) group } \\
\text { (group 21) }\end{array}$ & $\begin{array}{c}\text { CDP, X-linked dominant, Conradi-Hûnermann } \\
\text { type (CDPX2) } \\
\text { Greenberg dysplasia }\end{array}$ & $2(3)$ \\
\hline $\begin{array}{l}\text { Mesomelic and rhizo- } \\
\text { mesomelic dysplasias } \\
\text { (group 17) }\end{array}$ & Langer type (homozygous dyschondrosteosis) & $1(1)$ \\
\hline $\begin{array}{l}\text { Neonatal } \\
\text { osteosclerotic } \\
\text { dysplasias (group 22) }\end{array}$ & Blomstrand dysplasia & $1(1)$ \\
\hline
\end{tabular}

Table 1: Prevalence and pattern of skeletal dysplasias. prenatal diagnostic dilemma [3]. Similarly, a targeted molecular study is difficult in a situation of fortuitous prenatal detection of a SD. Thus, fetopathological examination after pregnancy interruption is important to provide an accurate diagnosis [1].

Here, taking into account the classification of genetic skeletal disorders, 2015 revision (Nosology 2015), we chose to classify the SD according to their most striking phenotypical and radiological criteria regardless of lethality. In a combined retrospective and prospective study, we have gathered radiological, macroscopic and histological data on fetuses diagnosed with SD following abortion, stillbirth and immediate postnatal death over an 8-years period (2009-2016) at the Department of Embryo-Fetopathology of Tunis. Of the 5995 fetal autopsies carried out, $72(1.2 \%)$ were diagnosed with SD. The prevalence and pattern of $\mathrm{SD}$ in fetopathological practice are reported in Table 1.

These 72 cases encompassed 13 of 42 groups of Nosology 2015. The more common Nosology groups of SD were osteogenesis imperfecta (29\%), fibroblast growth factor receptor type 3 (FGFR3) chondrodysplasias (25\%), ciliopathies with major skeletal involvement (12\%) and sulphation disorders (10\%). Fetal age at autopsy ranged from 12 to 40 weeks with a mean of 22 weeks. There was a slight predilection for male gender among SD (male to female ratio: 1.15).

In conclusion, we have mentioned the commonly observed SD in fetopathology without being able to be exhaustive. Thus, our brief comment points to the great diversity and complexity of these disorders. Their enumeration and comprehension are far from being complete. Therefore, fetopathological examination is of extremely great importance as it allows to give an accurate diagnosis, guide the genetic study and provide genetic counseling.

\section{References}

1. Barkova E, Mohan U, Chitayat D, Keating S, Toi A, et al. (2015) Fetal skeletal dysplasias in a tertiary care center: Radiology, pathology and molecular analysis of 112 cases. Clin Genet 87: 330-337.

2. Bonafe L, Cormier-Daire V, Hall C, Lachman R, Mortier G, et al. (2015) Nosology and classification of genetic skeletal disorders: 2015 revision. Am J Med Gene A 167A: 2869-2892.

3. Milks KS, Hill LM, Hosseinzadeh K (2017) Evaluating skeletal dysplasias on prenatal ultrasound: An emphasis on predicting lethality. Pediatr Radiol 47: 134145.

*Corresponding author: Sihem Darouich, University Hospital Habib Bougatfa, Bizerte, Tunisia, E-mail: sihem.darouich@free.fr

Received June 23, 2017; Accepted June 24, 2017; Published Junly 01, 2017

Citation: Darouich S, Boujelbene N, Gaigi S, Masmoudi A (2017) Usefulness of Fetopathological Examination in the Diagnosis of Skeletal Dysplasias. J Clin Med Genomics 5: e103. doi: 10.4172/2472-128X.1000e103

Copyright: () 2017 Darouich S, et al. This is an open-access article distributed under the terms of the Creative Commons Attribution License, which permits unrestricted use, distribution, and reproduction in any medium, provided the original author and source are credited. 